\title{
Tuberculosis Incidence Trends from 1990 to 2017 Highlight Impact of Drug Resistance: Results from the Global Burden of Disease Study
}

\section{Zejin Ou}

Southern Medical University

Wenqiao He

Southern Medical University

Danfeng Yu

Guangdong Women and Children Hospital

Yongzhi Li

Southern Medical University

Yuanhao Liang

Southern Medical University

Minyi Zhang

Southern Medical University

Huan He

Southern Medical University

Yuhan Gao

Southern Medical University

Fei Wu

Southern Medical University

Qing Chen ( $\sim$ qch.2009@163.com)

Southern Medical University https://orcid.org/0000-0002-8450-9300

\section{Research Article}

Keywords: Tuberculosis, Global burden of disease, Age-standardised rate, Estimated annual percentage change, Drug resistance

Posted Date: September 21st, 2020

DOI: https://doi.org/10.21203/rs.3.rs-78132/v1

License: (c) (1) This work is licensed under a Creative Commons Attribution 4.0 International License.

Read Full License 


\section{Abstract}

Objectives This study aimed to determine the global incidence trends of tuberculosis (TB) from 1990 to 2017.

Methods Data was obtained from the Global Burden of Disease (GBD) study. The estimated annual percentage changes (EAPCs) were calculated with the age-standardised incidence rate (ASIR) to estimate trends in incidence of TB, including multidrug-resistant TB (MDR-TB) and extensively drug-resistant tuberculosis (XDR-TB).

Results Globally, the number of TB cases was $8965.81 \times 10^{3}$ in 2017 , with a $9.42 \%$ increase since 1990 . The ASIR for TB showed a decreasing trend from 1990 to 2017 (EAPC $=-1.19,95 \%$ confidence interval [CI]: -1.32 to -1.07). Meanwhile, decreasing trends were observed in 162 countries/territories, particularly in Ethiopia and China where EAPCs were -4.51 (95\% Cl: -5.22 to -3.80$)$ and -4.21 (95\% Cl: -4.98 to -3.44), respectively. However, obvious increasing trends of MDR-TB cases occurred in areas with low and low-middle sociodemographic indexes (SDI), with EAPCs of 7.97 (95\% Cl: 2.47 to 13.75) and 6.30 (95\%:1.17 to 11.68), respectively. The ASIR for XDR-TB showed pronounced increasing trends globally from 1991 to 2017, with an EAPC of 11.74 (95\%Cl: 7.50 to 16.16). The largest rising trends of XDR-TB were observed in Kyrgyzstan (EAPC $=31.06,95 \% \mathrm{Cl}: 23.07$ to 39.57 ), followed by Azerbaijan and Uzbekistan.

Conclusions There was a decreasing trend for TB incidence worldwide, although it was more pronounced in specific countries and regions. However, the rapidly rising trends of MDR-TB and XDR-TB cases in low and low-middle SDI areas and countries may have an adverse impact on the global control of TB.

\section{Introduction}

Tuberculosis (TB) is one of the most important infectious diseases worldwide, and significant success in controlling the transmission of the infection has been achieved. However, antituberculosis drug resistance has become an important health concern in recent years (1).

Over the past decades, epidemiological patterns of TB have changed dramatically. In 2008, over 9 million new cases of TB were diagnosed worldwide, and more than one million individuals died (2). In recent years, there has been a declining trend in the global incidence and mortality rates of TB (3). The 2018 Global Tuberculosis Report reported that the incidence of TB fell by about $2 \%$ per year during 2000-2017 (4). However, global control of TB is strongly influenced by antituberculosis drug resistant bacteria (5). Multidrug-resistant tuberculosis (MDR-TB) is caused by Mycobacterium tuberculosis strains, which are resistant to at least isoniazid (INH) and rifampin (6). In 1994, the World Health Organization (WHO) launched a global program on surveillance of drug-resistant tuberculosis, and the results showed that the occurrence of MDR-TB had increased dramatically worldwide (7). Globally, MDR-TB was estimated to be approximately 460,000 cases in 2017 , which accounted for $3.6 \%$ of all new cases and $17 \%$ of previously treated cases (4). China, India, Russia, and South Africa experienced the highest burden of MDR-TB, 
accounting for as much as $>60 \%$ of all cases globally (8). Furthermore, an estimated $6.7 \%$ of MDR-TB patients were also resistant to fluoroquinolones and second-line injectable drugs, and these cases are defined as extensively drug-resistant tuberculosis (XDR-TB) $(4,9)$. Furthermore, this scenario worsened following an inundation of drug use and human immunodeficiency virus (HIV) infection, which accelerated the development of drug resistance (10).

Antituberculosis drug resistance has become an increasing threat to global public health. Therefore, it is necessary to track trends in TB burden including MDR-TB and XDR-TB with the latest data from the Global Burden of Disease (GBD) study. In this study, we investigated the incident trends of TB from 1990 to 2017 to facilitate improvement of TB control strategies.

\section{Methods}

\section{Data source}

Data sources for the TB burden were explored using the Global Health Data Exchange (GHDx) query tool (http://ghdx.healthdata.org/gbd-results-tool). We obtained data on the incidence of TB and MDR-TB from 1990 to 2017 stratified by sex, age, subtype, sociodemographic index (SDI) area, geographic region, and country, whereas data relative to XDR-TB were available from 1991 to 2017. The SDI was classified into 5 categories: low, low-middle, middle, high-middle, and high. Data was available for 21 geographic regions and 195 countries/territories worldwide. The methodologies for estimation of disease burden have been described in detail in previous studies (11). Data on the Human Development Index (HDI) were obtained from the United Nations Development Program (http://hdr.undp.org/en/data).

\section{Statistical analysis}

The age-standardised rate (ASR) is a necessary and representative index when considering differences in the age structure of multiple populations, and is calculated using the following formula:

$$
\mathrm{ASR}=\frac{\sum_{i=1}^{A} a_{i} w_{i}}{\sum_{i=1}^{A} w_{i}} \times 100,000
$$

where $a_{i}$ is the age-specific rate in the $t^{\text {th }}$ age group, $w$ is the number of people (or the weight) in the corresponding $t^{\text {th }}$ age group from among the selected reference standard population, and $A$ is the number of age groups.

The estimated annual percentage changes (EAPCs) is a reliable method for describing the magnitude of the trends in ASR (12). A regression line is fitted to the natural logarithm of the rates, for example, $y=a+$ $\beta x+\varepsilon$, where $y=\ln (A S R)$ and $x=$ calendar year. The EAPC was estimated as $100 \times(\exp (\beta)-1)$, and its $95 \%$ confidence interval was calculated using the linear regression model. Based on the above calculations, trends were assessed as follows: the EAPC value and respective $95 \% \mathrm{Cl}>0$ was used to define an 
increasing trend in ASR; and the EAPC value and respective $95 \% \mathrm{Cl}<0$ defined a decreasing trend in ASR; other values indicated that ASR was stable over time. Pearson's correlation analysis was used to detect factors influencing EAPCs at a national level, including ASR and HDI in 1990 and 2017. Data were analysed using the Statistical Package for Social Sciences (SPSS; version 25.0; SPSS Inc., Chicago, IL, USA). Choropleth maps were drawn using an R program (version 3.6.2).

\section{Results}

\section{Trends in incidence of TB}

Globally, the incidence of TB was $8965.81 \times 10^{3}\left(95 \% \mathrm{Ul}: 8191.85 \times 10^{3}\right.$ to $\left.9820.79 \times 10^{3}\right)$ in 2017 , corresponding to an increase of $9.42 \%$ from 1990 (Table 1). The overall ASIR decreased by an annual average of $1.19 \%$ during $1990-2017$ (EAPC $=-1.19,95 \% \mathrm{Cl}:-1.25$ to -1.13$)$. The decreasing trend in ASIR of TB was more obvious in females, with the EAPC of $-1.28(95 \% \mathrm{Cl}:-1.35$ to -1.21$)$. When comparing different age groups, the highest increase in number of TB cases was observed in age groups above 70 years, and a decrease in the number of TB cases occurred in age groups under 14 globally (see web-only Supplementary Table S1). Decreasing trends of TB were observed in most SDI areas and geographic regions. All SDI areas showed a decreasing trend of ASIR, particularly in high-middle SDI areas $(\mathrm{EAPC}=-2.83,95 \% \mathrm{Cl}:-3.07$ to -2.59$)$. In terms of geographic regions, the largest increase in incidence was found in Central Sub-Saharan Africa (81.66\%), followed by Oceania (64.78\%) and Eastern Sub-Saharan Africa (62.39\%), while the largest decrease was in East Asia (-49.05\%) (Table 1). The decreasing trends in ASIR of TB occurred in 19 geographic regions, and those with the largest decrease were in East Asia (EAPC $=-4.05,95 \% \mathrm{Cl}$ : -4.38 to -3.72 ), followed by Andean Latin America and highincome North America (Table 1, Figs. 1 and 2). Among the 195 countries/territories, the highest increased change in the incidence of TB cases occurred in the United Arab Emirates (257.45\% increase), while the strongest decrease (-58.62\%) was seen in Estonia (see web-only Supplementary Table S2, Fig. 3). The ASIR of TB showed decreasing trends in 168 countries/territories, particularly in Ethiopia and China, in which the EAPCs were $-4.51(95 \% \mathrm{Cl}:-5.00$ to -4.02$)$ and $-4.21(95 \% \mathrm{Cl}:-4.56$ to -3.87$)$, respectively (see web-only Supplementary Table S2, Fig. 3). However, increasing trends occurred in 17 countries/territories, and the largest increase occurred in Kenya (EAPC $=2.10,95 \% \mathrm{Cl}: 1.71$ to 2.49), followed by Lesotho and Ukraine (see web-only Supplementary Table S2, Fig. 3). The EAPCs (20002017) showed a positive correlation with the ASIR in 1990, and a negative association with the HDI in 2017 at a national level $(\rho=0.23, p=0.01$, Fig. 10A; $\rho=-0.26, p<0.001$, Fig. 10B, respectively). 
Table 1

The number and age-standardised rate of tuberculosis incidence globally and stratified by sex, SDI areas and geographic regions in 1990 and 2017, and the percentage change in the absolute number of cases and the EAPCs from 1990 to 2017

\begin{tabular}{|c|c|c|c|c|c|c|}
\hline & 1990 & & 2017 & & 1990-2017 & \\
\hline Characteristics & $\begin{array}{l}\text { Number } \\
\text { No.×1033 } \\
(95 \% \text { UI) }\end{array}$ & $\begin{array}{l}\text { ASR per } \\
100 \mathrm{k} \\
\text { No. (95\% } \\
\text { UI) }\end{array}$ & $\begin{array}{l}\text { Number } \\
\text { No.×1033 } \\
(95 \% \text { UI) }\end{array}$ & $\begin{array}{l}\text { ASR per } \\
100 \mathrm{k} \\
\text { No. (95\% } \\
\text { UI) }\end{array}$ & $\begin{array}{l}\text { Percentage } \\
\text { change in } \\
\text { absolute } \\
\text { number (\%) }\end{array}$ & $\begin{array}{l}\text { EAPCs } \\
\text { No. } \\
(95 \% \mathrm{Cl})\end{array}$ \\
\hline Overall & $\begin{array}{l}8194.03 \\
(7476.18- \\
9014.58)\end{array}$ & $\begin{array}{l}156.59 \\
(143.02- \\
171.37)\end{array}$ & $\begin{array}{l}8965.81 \\
(8191.85- \\
9820.79)\end{array}$ & $\begin{array}{l}115.78 \\
(105.79- \\
126.95)\end{array}$ & 9.42 & $\begin{array}{l}-1.19 \\
(-1.25 \text { to } \\
-1.13)\end{array}$ \\
\hline Sex & & & & & & \\
\hline Male & $\begin{array}{l}4213.78 \\
(3845.21- \\
4609.42)\end{array}$ & $\begin{array}{l}167.53 \\
(153.86- \\
182.49)\end{array}$ & $\begin{array}{l}4913.77 \\
(4499.26- \\
5375.83)\end{array}$ & $\begin{array}{l}126.57 \\
(116.25- \\
137.97)\end{array}$ & 16.61 & $\begin{array}{l}-1.13 \\
(-1.20 \text { to } \\
-1.07)\end{array}$ \\
\hline Female & $\begin{array}{l}3980.25 \\
(3616.03- \\
4389.58)\end{array}$ & $\begin{array}{l}148.16 \\
(135.07- \\
163.1)\end{array}$ & $\begin{array}{l}4052.04 \\
(3689.23- \\
4447.33)\end{array}$ & $\begin{array}{l}106.17 \\
(96.62- \\
116.67)\end{array}$ & 1.80 & $\begin{array}{l}-1.28 \\
(-1.35 \text { to } \\
-1.21)\end{array}$ \\
\hline SDI & & & & & & \\
\hline Low & $\begin{array}{l}2147.49 \\
(1964.12- \\
2354.29)\end{array}$ & $\begin{array}{l}377.33 \\
(346.05- \\
410.62)\end{array}$ & $\begin{array}{l}3081.85 \\
(2809.34- \\
3392.95)\end{array}$ & $\begin{array}{l}277.77 \\
(255.4- \\
302.38)\end{array}$ & 43.51 & $\begin{array}{l}-1.18 \\
(-1.25 \text { to } \\
-1.12)\end{array}$ \\
\hline Low-middle & $\begin{array}{l}2403.69 \\
(2198.44- \\
2639.18)\end{array}$ & $\begin{array}{l}268.08 \\
(247.07- \\
290.59)\end{array}$ & $\begin{array}{l}2940.34 \\
(2684.15- \\
3229.73)\end{array}$ & $\begin{array}{l}185.65 \\
(170.59- \\
201.77)\end{array}$ & 22.33 & $\begin{array}{l}-1.38 \\
(-1.45 \text { to } \\
-1.31)\end{array}$ \\
\hline Middle & $\begin{array}{l}2431.81 \\
(2205.75- \\
2688.37)\end{array}$ & $\begin{array}{l}169.49( \\
154.83- \\
185.08)\end{array}$ & $\begin{array}{l}2123.69 \\
(1941.70- \\
2325.71)\end{array}$ & $\begin{array}{l}98.20 \\
(89.85- \\
107.32)\end{array}$ & -12.67 & $\begin{array}{l}-2.02 \\
(-2.06 \text { to } \\
-1.99)\end{array}$ \\
\hline High-middle & $\begin{array}{l}963.52 \\
(873.52- \\
1065.25)\end{array}$ & $\begin{array}{l}86.77 \\
(79.00- \\
95.58)\end{array}$ & $\begin{array}{l}666.03 \\
(608.42- \\
729.37)\end{array}$ & $\begin{array}{l}43.78 \\
(39.97- \\
47.72)\end{array}$ & -30.88 & $\begin{array}{l}-2.83 \\
(-3.07 \text { to } \\
-2.59)\end{array}$ \\
\hline
\end{tabular}

EAPC: estimated annual percentage change; ASR, age-standardised rate; $\mathrm{Cl}$, confidence interval; $\mathrm{UI}$ : uncertainty interval; SDI: socio-demographic index. Percentage change in absolute number was calculated based on the crude data. 


\begin{tabular}{|c|c|c|c|c|c|c|}
\hline & 1990 & & 2017 & & 1990-2017 & \\
\hline \multirow[t]{2}{*}{ High } & 214.91 & 20.64 & 135.65 & 9.98 & -36.88 & -2.71 \\
\hline & $\begin{array}{l}(191.96- \\
241.01)\end{array}$ & $\begin{array}{l}(18.42- \\
23.3)\end{array}$ & $\begin{array}{l}(125.09- \\
146.93)\end{array}$ & $\begin{array}{l}(9.13- \\
10.90)\end{array}$ & & $\begin{array}{l}(-2.82 \text { to } \\
-2.60)\end{array}$ \\
\hline \multicolumn{7}{|l|}{ Regions } \\
\hline \multirow[t]{2}{*}{ East Asia } & 1770.77 & 144.88 & 902.29 & 55.94 & -49.05 & -4.05 \\
\hline & $\begin{array}{l}\text { (1610.58- } \\
1954.82)\end{array}$ & $\begin{array}{l}(132.56- \\
158.41)\end{array}$ & $\begin{array}{l}(823.24- \\
987.73)\end{array}$ & $\begin{array}{l}(51.06- \\
61.02)\end{array}$ & & $\begin{array}{l}(-4.38 \text { to } \\
-3.72)\end{array}$ \\
\hline \multirow[t]{2}{*}{ South Asia } & 2734.76 & 294.27 & 3432.76 & 205.34 & 25.52 & -1.29 \\
\hline & $\begin{array}{l}(2493.13- \\
3018.24)\end{array}$ & $\begin{array}{l}(269.81- \\
320.92)\end{array}$ & $\begin{array}{l}(3132.77- \\
3765.86)\end{array}$ & $\begin{array}{l}(188.55- \\
224.02)\end{array}$ & & $\begin{array}{l}(-1.35 \text { to } \\
-1.23)\end{array}$ \\
\hline \multirow[t]{2}{*}{ Southeast Asia } & 1023.97 & 251.89 & 964.54 & 149.42 & -5.80 & -1.90 \\
\hline & $\begin{array}{l}(929.33- \\
1138.69)\end{array}$ & $\begin{array}{l}(230.31- \\
275.82)\end{array}$ & $\begin{array}{l}(878.85- \\
1056.06)\end{array}$ & $\begin{array}{l}(136.93- \\
162.47)\end{array}$ & & $\begin{array}{l}(-2.07 \text { to } \\
-1.74)\end{array}$ \\
\hline \multirow[t]{2}{*}{ Central Asia } & 63.38 & 94.63 & 73.65 & 79.05 & 16.20 & -0.86 \\
\hline & $\begin{array}{l}(56.91- \\
70.58)\end{array}$ & $\begin{array}{l}(85.28- \\
104.85)\end{array}$ & $\begin{array}{l}(67.25- \\
80.66)\end{array}$ & $\begin{array}{l}(72.39- \\
85.96)\end{array}$ & & $\begin{array}{l}(-1.32 \text { to } \\
-0.40)\end{array}$ \\
\hline High-income & 91.05 & 47.90 & 56.77 & 20.91 & -37.65 & -2.73 \\
\hline Asia Pacific & $\begin{array}{l}(80.64- \\
102.64)\end{array}$ & $\begin{array}{l}(42.49- \\
54.13)\end{array}$ & $\begin{array}{l}(52.33- \\
61.3)\end{array}$ & $\begin{array}{l}(19.21- \\
22.73)\end{array}$ & & $\begin{array}{l}(-3.06 \text { to } \\
-2.40)\end{array}$ \\
\hline \multirow[t]{2}{*}{ Oceania } & 9.88 & 176.37 & 16.28 & 138.76 & 64.78 & -1.10 \\
\hline & $\begin{array}{l}(8.96- \\
10.97)\end{array}$ & $\begin{array}{l}(161.53- \\
192.86)\end{array}$ & $\begin{array}{l}(14.69- \\
18.16)\end{array}$ & $\begin{array}{l}(126.33- \\
152.26)\end{array}$ & & $\begin{array}{l}(-1.29 \text { to } \\
-0.91)\end{array}$ \\
\hline \multirow[t]{2}{*}{ Australasia } & 1.57 & 7.55 & 1.65 & 5.68 & 5.10 & -0.81 \\
\hline & $\begin{array}{l}(1.38- \\
1.79)\end{array}$ & $\begin{array}{l}(6.64- \\
8.6)\end{array}$ & $\begin{array}{l}(1.50- \\
1.79)\end{array}$ & $\begin{array}{l}(5.15- \\
6.22)\end{array}$ & & $\begin{array}{l}(-1.05 \text { to } \\
-0.56)\end{array}$ \\
\hline \multirow[t]{2}{*}{ Eastern Europe } & 144.22 & 61.11 & 141.27 & 60.32 & -2.05 & 0.21 \\
\hline & $\begin{array}{l}(128.78- \\
161.67)\end{array}$ & $\begin{array}{l}(54.60- \\
68.50)\end{array}$ & $\begin{array}{l}(126.67- \\
157.05)\end{array}$ & $\begin{array}{l}(54.23- \\
66.78)\end{array}$ & & $\begin{array}{l}(-0.32- \\
0.75)\end{array}$ \\
\hline \multirow[t]{2}{*}{ Western Europe } & 51.51 & 13.17 & 31.81 & 7.89 & -38.25 & -1.66 \\
\hline & $\begin{array}{l}(45.21- \\
59.13)\end{array}$ & $\begin{array}{l}(11.52- \\
15.21)\end{array}$ & $\begin{array}{l}(28.91- \\
34.97)\end{array}$ & $\begin{array}{l}(7.06- \\
8.79)\end{array}$ & & $\begin{array}{l}(-1.78 \text { to } \\
-1.54)\end{array}$ \\
\hline
\end{tabular}

EAPC: estimated annual percentage change; ASR, age-standardised rate; $\mathrm{Cl}$, confidence interval; Ul: uncertainty interval; SDI: socio-demographic index. Percentage change in absolute number was calculated based on the crude data. 


\begin{tabular}{|c|c|c|c|c|c|c|}
\hline & 1990 & & 2017 & & 1990-2017 & \\
\hline \multirow[t]{2}{*}{ Central Europe } & 39.77 & 30.27 & 26.62 & 19.94 & -33.07 & -2.03 \\
\hline & $\begin{array}{l}(35.64- \\
43.91)\end{array}$ & $\begin{array}{l}(27.18- \\
33.54)\end{array}$ & $\begin{array}{l}(24.63- \\
28.67)\end{array}$ & $\begin{array}{l}(18.38- \\
21.51)\end{array}$ & & $\begin{array}{l}(-2.34 \text { to } \\
-1.72)\end{array}$ \\
\hline \multirow{2}{*}{$\begin{array}{l}\text { High-income } \\
\text { North America }\end{array}$} & 15.65 & 5.18 & 9.69 & 2.51 & -38.08 & -3.11 \\
\hline & $\begin{array}{l}(13.84- \\
17.64)\end{array}$ & $\begin{array}{l}(4.59- \\
5.87)\end{array}$ & $\begin{array}{l}(8.73- \\
10.84)\end{array}$ & $\begin{array}{l}(2.25- \\
2.81)\end{array}$ & & $\begin{array}{l}(-3.4 \text { to } \\
-2.82)\end{array}$ \\
\hline \multirow{2}{*}{$\begin{array}{l}\text { Andean Latin } \\
\text { America }\end{array}$} & 54.17 & 158.70 & 40.43 & 66.55 & -25.36 & -3.69 \\
\hline & $\begin{array}{l}(49.36- \\
59.64)\end{array}$ & $\begin{array}{l}(146.05- \\
172.85)\end{array}$ & $\begin{array}{l}(36.97- \\
44.36)\end{array}$ & $\begin{array}{l}(61.03- \\
72.81)\end{array}$ & & $\begin{array}{l}(-4.01 \text { to } \\
-3.38)\end{array}$ \\
\hline \multirow{2}{*}{$\begin{array}{l}\text { Central Latin } \\
\text { America }\end{array}$} & 37.17 & 29.06 & 47.37 & 18.65 & 27.44 & -2.13 \\
\hline & $\begin{array}{l}(33.69- \\
41.14)\end{array}$ & $\begin{array}{l}(26.62- \\
31.77)\end{array}$ & $\begin{array}{l}(43.28- \\
52.2)\end{array}$ & $\begin{array}{l}(17.09- \\
20.49)\end{array}$ & & $\begin{array}{l}(-2.34 \text { to } \\
-1.93)\end{array}$ \\
\hline \multirow[t]{2}{*}{ Caribbean } & 15.93 & 45.75 & 15.71 & 33.41 & -1.38 & -1.23 \\
\hline & $\begin{array}{l}(14.58- \\
17.5)\end{array}$ & $\begin{array}{l}(41.97- \\
50.06)\end{array}$ & $\begin{array}{l}(14.31- \\
17.28)\end{array}$ & $\begin{array}{l}(30.34- \\
36.68)\end{array}$ & & $\begin{array}{l}(-1.42 \text { to } \\
-1.05)\end{array}$ \\
\hline \multirow{2}{*}{$\begin{array}{l}\text { Tropical Latin } \\
\text { America }\end{array}$} & 58.35 & 42.48 & 70.87 & 30.03 & 21.46 & -1.65 \\
\hline & $\begin{array}{l}(51.97- \\
65.98)\end{array}$ & $\begin{array}{l}(38.07- \\
47.71)\end{array}$ & $\begin{array}{l}(63.5- \\
79.84)\end{array}$ & $\begin{array}{l}(26.89- \\
33.7)\end{array}$ & & $\begin{array}{l}(-1.79 \text { to } \\
-1.50)\end{array}$ \\
\hline \multirow{2}{*}{$\begin{array}{l}\text { Southern Latin } \\
\text { America }\end{array}$} & 10.64 & 21.72 & 8.48 & 12.53 & -20.30 & -2.31 \\
\hline & $\begin{array}{l}(9.59- \\
11.88)\end{array}$ & $\begin{array}{l}(19.62- \\
24.21)\end{array}$ & $\begin{array}{l}(7.85- \\
9.15)\end{array}$ & $\begin{array}{l}(11.57- \\
13.54)\end{array}$ & & $\begin{array}{l}(-2.54 \text { to } \\
-2.08)\end{array}$ \\
\hline \multirow{2}{*}{$\begin{array}{l}\text { Eastern Sub- } \\
\text { Saharan Africa }\end{array}$} & 691.34 & 442.10 & 1122.69 & 315.86 & 62.39 & -1.34 \\
\hline & $\begin{array}{l}(631.29- \\
757.06)\end{array}$ & $\begin{array}{l}(404.97- \\
483.88)\end{array}$ & $\begin{array}{l}(1021.94- \\
1238.74)\end{array}$ & $\begin{array}{l}(289.27- \\
346.1)\end{array}$ & & $\begin{array}{l}(-1.55 \text { to } \\
-1.13)\end{array}$ \\
\hline \multirow{2}{*}{$\begin{array}{l}\text { Southern Sub- } \\
\text { Saharan Africa }\end{array}$} & 272.85 & 528.83 & 345.38 & 430.09 & 26.58 & 0.52 \\
\hline & $\begin{array}{l}(246.01- \\
301.34)\end{array}$ & $\begin{array}{l}(480.24- \\
580.35)\end{array}$ & $\begin{array}{l}(308.85- \\
386.87)\end{array}$ & $\begin{array}{l}(388.77- \\
477.49)\end{array}$ & & $\begin{array}{l}(0.09- \\
0.95)\end{array}$ \\
\hline \multirow{2}{*}{$\begin{array}{l}\text { Western Sub- } \\
\text { Saharan Africa }\end{array}$} & 615.49 & 393.42 & 912.74 & 258.94 & 48.29 & -1.70 \\
\hline & $\begin{array}{l}(565.31- \\
671.29)\end{array}$ & $\begin{array}{l}(362.79- \\
426.17)\end{array}$ & $\begin{array}{l}(836.25- \\
999.91)\end{array}$ & $\begin{array}{l}(238.85- \\
282.09)\end{array}$ & & $\begin{array}{l}(-1.79 \text { to } \\
-1.62)\end{array}$ \\
\hline
\end{tabular}

EAPC: estimated annual percentage change; ASR, age-standardised rate; $\mathrm{Cl}$, confidence interval; $\mathrm{UI}$ : uncertainty interval; SDI: socio-demographic index. Percentage change in absolute number was calculated based on the crude data. 


\begin{tabular}{|c|c|c|c|c|c|c|}
\hline & \multicolumn{2}{|l|}{1990} & \multicolumn{2}{|l|}{2017} & \multicolumn{2}{|c|}{ 1990-2017 } \\
\hline North Africa and & 221.10 & 71.41 & 253.52 & 43.44 & 14.66 & -1.99 \\
\hline Middle East & $\begin{array}{l}(200.94- \\
243.18)\end{array}$ & $\begin{array}{l}(65.35- \\
78.11)\end{array}$ & $\begin{array}{l}(228.39- \\
281.59)\end{array}$ & $\begin{array}{l}(39.48- \\
47.93)\end{array}$ & & $\begin{array}{l}(-2.05 \text { to } \\
-1.93)\end{array}$ \\
\hline Central Sub- & 270.45 & 615.27 & 491.30 & 504.77 & 81.66 & -0.73 \\
\hline Africa & $\begin{array}{l}(245.85- \\
296.71)\end{array}$ & $\begin{array}{l}(562.23- \\
672.39)\end{array}$ & $\begin{array}{l}(443.99- \\
544.68)\end{array}$ & $\begin{array}{l}(459.88- \\
551)\end{array}$ & & $\begin{array}{l}(-0.82 \text { to } \\
-0.65)\end{array}$ \\
\hline
\end{tabular}

\section{Trends in incidence of MDR-TB}

Globally, the number of incident MRD-TB cases increased 642.57\% from 1990 to 2017, and was $432.77 \times$ $10^{3}$ (95\% Ul: $254.61 \times 10^{3}-726.95 \times 10^{3}$ ) in 2017 (see web-only Supplementary Table S3, Fig. 1). The trend in ASIR of MDR-TB showed an increasing trend globally from 1990 to 2017, with an EAPC of 2.59 (95\% Cl: 1.01 to 4.20 ) (see web-only Supplementary Table S3). The largest increase in the number of incident cases of MDR-TB occurred in low SDI areas (4447.76\%) (see web-only Supplementary Table S3, see web-only Supplementary Figure S1). The ASIR of MDR-TB showed increasing trends in low-middle SDI areas, and particularly in low SDI areas (EAPC $=7.97,95 \% \mathrm{Cl}: 5.52$ to 10.46). For 21 geographic regions, the number of incident cases of MDR-TB decreased in East Asia and high-income North America, and conversely, increased in other regions, particularly in Central Asia (16566.67\%) (see web-only Supplementary Table S3 and Supplementary Figure S1). The increasing trends in ASIR were found in 10 geographic regions, especially in Central Asia (EAPC $=14.19,95 \% \mathrm{Cl}$ : 10.2 to 18.33 ), followed by Oceania and South Asia. Among the 195 countries/territories, the highest increase in the number of incident cases was observed in Azerbaijan (60486.61\%), whereas the highest decrease was observed in Slovenia (78.01\%) (see web-only Supplementary Table S6, Supplementary Figure S5). The ASIR for MDR-TB showed rising trends in 133 countries/territories, particularly Kyrgyzstan, Azerbaijan, and Uzbekistan, in which the EAPCs were 19.95 ( $95 \% \mathrm{Cl}$ : 15.54 to 24.52$), 18.86$ (95\% Cl: 14.5 to 23.39 ), and 18.84 (95\%Cl: 14.31 to 23.56), respectively. However, trends in the ASIR for MDR-TB decreased in 33 countries/territories, and the most pronounced decreases occurred in Slovenia and Japan, in which the EAPCs were -7.81 (95\%Cl: -9.77 to -5.79$)$ and $-6.77(95 \% \mathrm{Cl}$ : -8.51 to -4.99$)$, respectively (see webonly Supplementary Table S5 and Supplementary Figure S3). The EAPCs had a positive association with the HDI in 2017 at the national level ( $\rho=-0.20, p=0.01$, see web-only Supplementary Figure S5), but not with the ASIR in 1990.

\section{Incidence trends of XDR-TB}


Globally, the incident cases of XDR-TB increased $5726.19 \%$ from 1991 , and was $24.47 \times 10^{3}$ (95\% Ul: $17.68-35 \times 10^{3}$ ) in 2017 (see web-only Supplementary Table S4). The ASIR of XDR-TB showed an increasing trend (EAPC $=11.74,95 \% \mathrm{Cl}$ : 9.05 to 14.50 ) (see web-only Supplementary Table S4, Fig. 1). Increasing changes in the number of incident cases of XDR-TB were found across all age groups globally, especially in individuals aged between 50 and 69 years (Table S1, see web-only Supplementary Figure S2). Increasing trends in the ASIR for XDR-TB were observed stratifying cases by sex, SDI area, and geographic region from 1991 to 2017, and were particularly evident for the low and low-middle SDI areas, in which EAPCs were 20.30 (95\% Cl: 16.08 to 24.67 ) and 13.85 (95\%Cl: 11.12 to 16.65 ), respectively (see web-only Supplementary Table S4 and Supplementary Figure S2). Central Asia and Oceania had the most pronounced increasing trends, with the EAPCs of 25.46 (95\% Cl: 20.16 to 30.99$)$ and 24.75 (95\%Cl: 21.57 to 28.02), respectively. Furthermore, the pronounced increasing trends in ASIR of XDR-TB were observed in 192 countries/territories, particularly Kyrgyzstan, Azerbaijan, and Uzbekistan, in which the EAPCs were 31.06 (95\% Cl: 25.44 to 36.93$), 29.97$ (95\% Cl: 24.53 to 35.66), and 29.96 (95\% Cl: 24.15 to 36.06), respectively (see web-only Supplementary Tables S4 and S5, and Supplementary Figure S4). No association was found between EAPCs and the ASIR in 1990, and the HDI in 2017 at a national level.

\section{Discussion}

In this study, a decreasing trend in the global incidence of TB was observed from 1990 to 2017, likely due to effective strategies of disease prevention and control established in previous decades, such as poverty reduction, improvement in health infrastructure, vaccination programmes, and international cooperation (13). Differences in the incidence of TB existed in countries and regions based on demographic and socioeconomic status. The fastest decrease in ASR for TB occurred in high-middle and high SDI areas. This might also be associated with economic status and health-related behaviour (14). For example, East Asia had the fastest decline in the number of TB cases, which might be explained by a reduction in poverty and under-nutrition combined with increased funding for TB control activities (15). Meanwhile, the largest decrease in trend in ASIR of TB cases was observed in China. The Chinese government had achieved great success in the control of TB due to the revitalization of anti-TB programs in the 1990s. Meanwhile, national initiatives associated with anti-TB strategies were also endorsed, including reducing poverty, improving health infrastructure, and infectious disease management (16). However, an increasing trend still existed in several countries across Eastern Europe and Sub-Saharan Africa, characterised by population expansion, poverty, and poor health infrastructure (17). Several practical strategies, such as extensive scale-up of the availability of health extension workers and the adoption of the Directly Observed Treatment Short-Course strategy (18), probably explain why Ethiopia had the highest decline in ASIR of TB. However, increasing trends in DS-TB also occurred in some countries, such as Norway, a country with a previously low incidence of TB, which was probably attributed to the ageing population (19).

Targets were established for the End TB Strategy, for example, to reduce tuberculosis incidence by $80 \%$ in 2030 compared to 2015 (20). However, the rapid development of antituberculosis drug resistance has 
threatened the targeted strategies for TB control. The numbers of incident cases and ASIR for MDR-TB and XDR-TB have dramatically increased in areas of low and low-middle SDI areas and countries. In these areas and countries, poverty, malnutrition, and overloaded health systems were still the main social factors associated with the incidence of TB (21). The highest increased change in ASIR of MDR-TB and XDR-TB cases occurred in the former Soviet countries of Kyrgyzstan, Azerbaijan, and Uzbekistan, and was associated with TB patients having a higher risk of developing antituberculosis drug resistance (22), and in countries where there had been a lack of proper implementation of the DOTS strategy (23). Furthermore, the situation deteriorated further with the spread of drug use and increased incidence of HIV infection $(24,25)$. In contrast, only seven countries/territories showed a decrease in the trend of ASIR for MDR-TB cases, with the largest decrease being observed in Slovenia, where rigorous TB prevention and treatment programs had been established (26).

The limitations of this study should be considered. The GBD study incidence estimates depended on the quality and quantity of the collected data and on the potential biases from misclassification and/or miscoding of disease by different countries, which may have affected the accuracy and robustness of the results. The diagnosis and detection of drug resistance also varied across countries and over time, which may have caused a potential bias. Although age is an important factor, due to the limitations of the ASR formula, this study estimated trends using the percentage change in the incident number across age groups only.

\section{Conclusion}

This study found that there was a global decrease in the incidence of TB between 1990 and 2017 across most areas with different SDI and across different geographic regions. However, the rapidly increasing trend in resistance to antituberculosis drugs has had a significant impact on the control of TB worldwide. There remains a huge challenge in the global control of TB, and more efficient prevention and diagnostic strategies and increasing investment to health infrastructure are urgently needed.

\section{Declarations}

\section{Ethics approval and consent to participate}

Not applicable.

\section{Consent for publication}

Not applicable.

\section{Availability of data and materials}

All data generated or analysed during this study are included in this published article and its supplementary information files. 


\section{Conflict of interests}

The authors declare that they have no competing interests.

\section{Funding}

No funding was received for this study.

\section{Authors' contributions}

ZJO, WQH: Project administration and drafting.

DFY, YHL: Data analysis and validation.

YZL, YHG: Data analysis and visualization.

MYZ, HH, FW: Data collection and collation.

QC: supervision and drafting and editing.

All authors read and approved the final manuscript.

\section{Acknowledgements}

Not applicable.

\section{References}

1. Nathanson E NP, Uplekar M, Floyd K, Jaramillo E, Lonnroth K, Weil D, Raviglione M. MDR tuberculosis-critical steps for prevention and control. N Engl J Med. 2010;363(11):1050-8.

2. López de Goicoechea-Saiz ME, Sternberg F, Portilla-Sogorb J. Prevalence and associated risk factors of latent tuberculosis infection in a Spanish prison. Revista espanola de sanidad penitenciaria. 2018;20(1):4-10.

3. Koch A, Mizrahi V. Mycobacterium tuberculosis. Trends in microbiology. 2018;26(6):555-6.

4. WHO. Global tuberculosis report 2018. . Geneva, Switzerland: World Health Organization, 2018.

5. Dheda K GT, Maartens G, Dooley KE, McNerney R, Murray M, Furin J, Nardell EA, London L, Lessem E, Theron G, van Helden P, Niemann S, Merker M, Dowdy D, Van Rie A, Siu GK, Pasipanodya JG, Rodrigues C, Clark TG, Sirgel FA, Esmail A, Lin HH, Atre SR, Schaaf HS, Chang KC, Lange C, Nahid P, Udwadia ZF, Horsburgh CR Jr, Churchyard GJ, Menzies D, Hesseling AC, Nuermberger E, Mcllleron H, Fennelly KP, Goemaere E, Jaramillo E, Low M, Jara CM, Padayatchi N, Warren RM. The epidemiology, pathogenesis, transmission, diagnosis, and management of multidrug-resistant, extensively drugresistant, and incurable tuberculosis. Lancet Respir Med. 2017;5(17):291-360. 
6. Iseman MD, Goble M. Multidrug-resistant tuberculosis. The New England journal of medicine. 1996;334(4):267; author reply 8-9.

7. Falzon D DJ. World TB day: European countries report over 400,000 tuberculosis cases in 2004 . Euro Surveill. 2006;11(3):E060323 3.

8. Zignol M vGW, Falzon D, Sismanidis C, Glaziou P, Floyd K, Raviglione M. Surveillance of antituberculosis drug resistance in the world: an updated analysis, 2007-2010. Bull World Health Organ. 2012;90(2):111-9D.

9. Lange C CD, Furin J, Udwadia Z, Dheda K. Revising the definition of extensively drug-resistant tuberculosis. Lancet Respir Med. 2018;6(12):893-5.

10. van den Hof S, Tursynbayeva A, Abildaev T, Adenov M, Pak S, Ismailov S. HIV and multidrug-resistant tuberculosis: overlapping risk factors. Eur Respir J. 2015;45(2):567-9.

11. Allemani C, Matsuda T, Di Carlo V, Harewood R, Matz M, Niksic M, et al. Global surveillance of trends in cancer survival 2000-14 (CONCORD-3): analysis of individual records for 37513025 patients diagnosed with one of 18 cancers from 322 population-based registries in 71 countries. Lancet. 2018;391(10125):1023-75.

12. Liu Z, Jiang Y, Yuan H, Fang Q, Cai N, Suo C, et al. The trends in incidence of primary liver cancer caused by specific etiologies: Results from the Global Burden of Disease Study 2016 and implications for liver cancer prevention. Journal of hepatology. 2019;70(4):674-83.

13. Glaziou P FK, Raviglione MC. Global Epidemiology of Tuberculosis. Semin Respir Crit Care Med. 2018;39(3):271-85.

14. Glaziou P, Floyd K, Raviglione MC. Global Epidemiology of Tuberculosis. Seminars in respiratory and critical care medicine. 2018;39(3):271-85.

15. Fryatt RJ. Tuberculosis control in South East Asia: vignettes from China, Cambodia and Myanmar. Health policy and planning. 2017;32(suppl_2):i1-i2.

16. Zhao P LX, Zhang SF, Wang XS, Liu CY. Social behaviour risk factors for drug resistant tuberculosis in mainland China: a meta-analysis. J Int Med Res. 2012;40(2):436-45.

17. Marais BJ, Raviglione MC, Donald PR, Harries AD, Kritski AL, Graham SM, et al. Scale-up of services and research priorities for diagnosis, management, and control of tuberculosis: a call to action. Lancet. 2010;375(9732):2179-91.

18. Cardoso G, Dos Santos EM, Kiflie Y, Woldemichael K, Wilson S, Lemma W. Strategic analysis of tuberculosis prevention and control actions in Brazil and Ethiopia: one size fits all? International journal of public health. 2017;62(2):305-15.

19. Schein YL, Madebo T, Andersen HE, Arnesen TM, Dyrhol-Riise AM, Tveiten H, et al. Treatment completion for latent tuberculosis infection in Norway: a prospective cohort study. 2018;18(1):587.

20. WHO. The WHO End TB Strategy. Geneva, Switzerland: World Health Organization, 2015.

21. Abubakar I, Zignol M, Falzon D, Raviglione M, Ditiu L, Masham S, et al. Drug-resistant tuberculosis: time for visionary political leadership. Lancet Infect Dis. 2013;13(6):529-39. 
22. Falzon D IA, Ait-Belghiti F. In the European Union, TB patients from former Soviet countries have a high risk of multidrug resistance. International Journal of Tuberculosis and Lung Disease. 2006;10(9):954-8.

23. Rashedi J, Mahdavi Poor B, Rafı A, Asgharzadeh M, Abdolalizadeh J, Moaddab SR. Multidrugresistant tuberculosis in north-west of Iran and Republic of Azerbaijan: a major public health concern for Iranian people. Journal of research in health sciences. 2015;15(2):101-3.

24. Schluge N, El-Bassel N, Hermosilla S, Terlikbayeva A, Darisheva M, Aifah A, Galea S. Tuberculosis, drug use and HIV infection in Central Asia: an urgent need for attention. Drug Alcohol Depend. 2013;132 Suppl 1:S32-6.

25. Harries AD HN, Kemp J, Jindani A, Enarson DA, Maher D, Salaniponi FM. Deaths from tuberculosis in sub-Saharan African countries with a high prevalence of HIV-1. Lancet. 2001;357(9267):1519-23.

26. Drobniewski FA, Balabanova YM. The diagnosis and management of multiple-drug-resistanttuberculosis at the beginning of the new millenium. Int $\mathrm{J}$ Infect Dis. 2002;6 Suppl 1:S21-31.

\section{Figures}

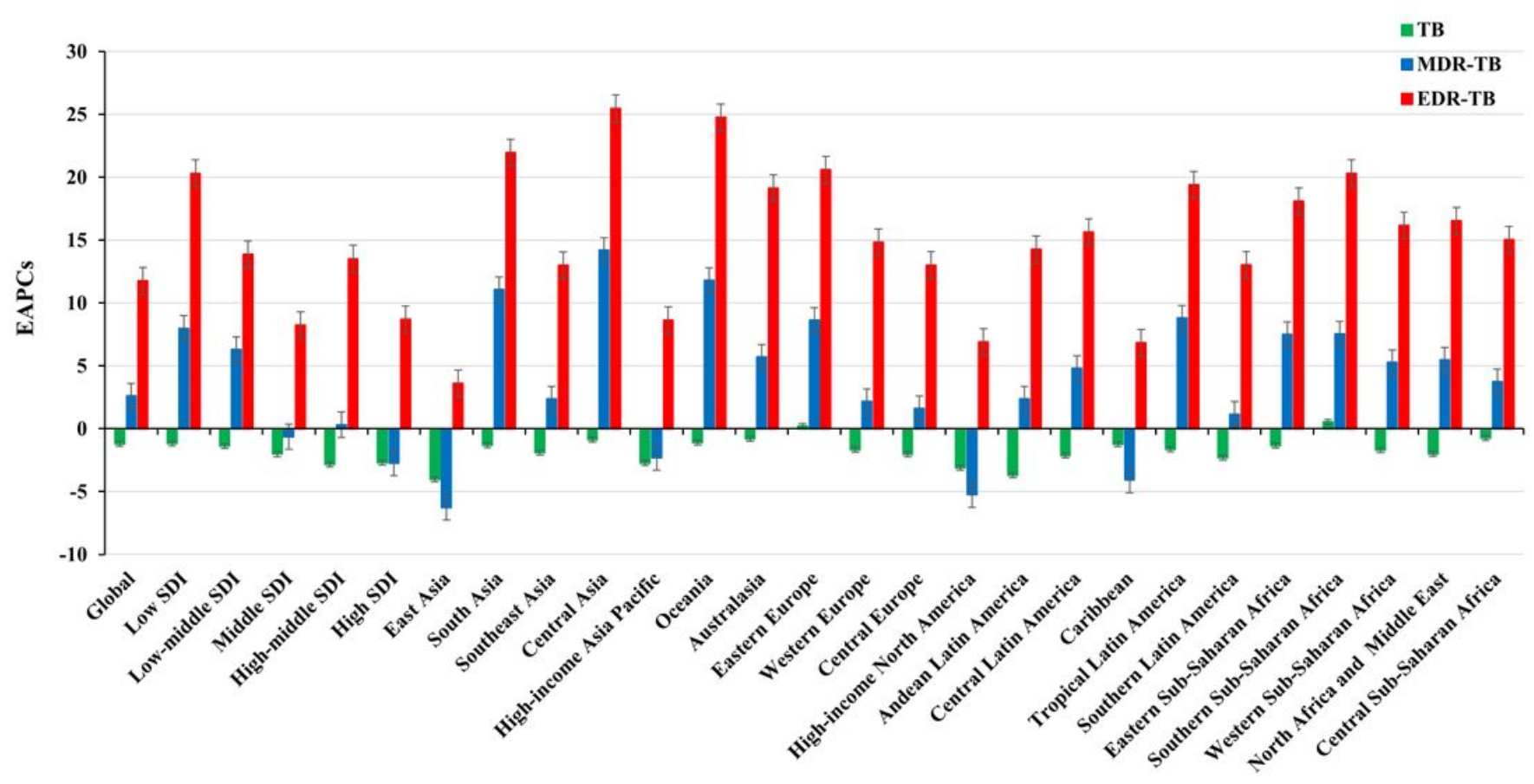

Figure 1

Trends in TB burden including TB, MDR-TB, and XDR-TB, globally and stratified by SDI areas and geographic regions from 1990 to 2017. 
(A)

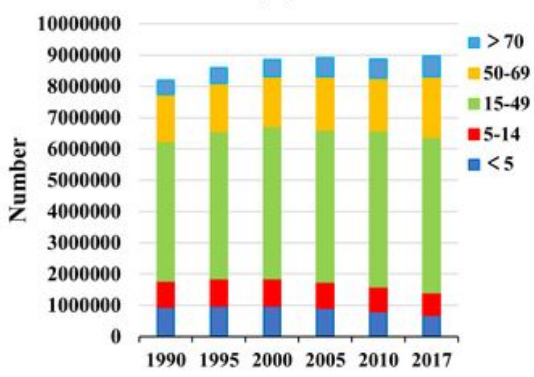

(B)

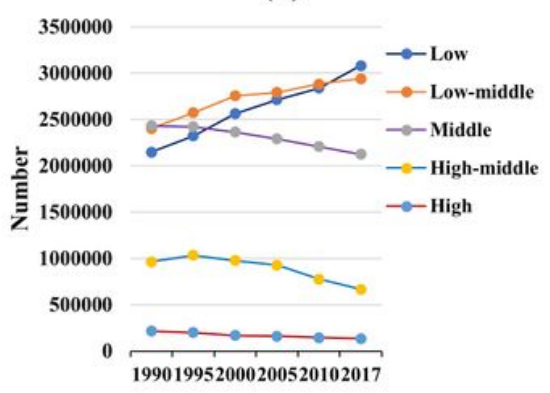

(C)

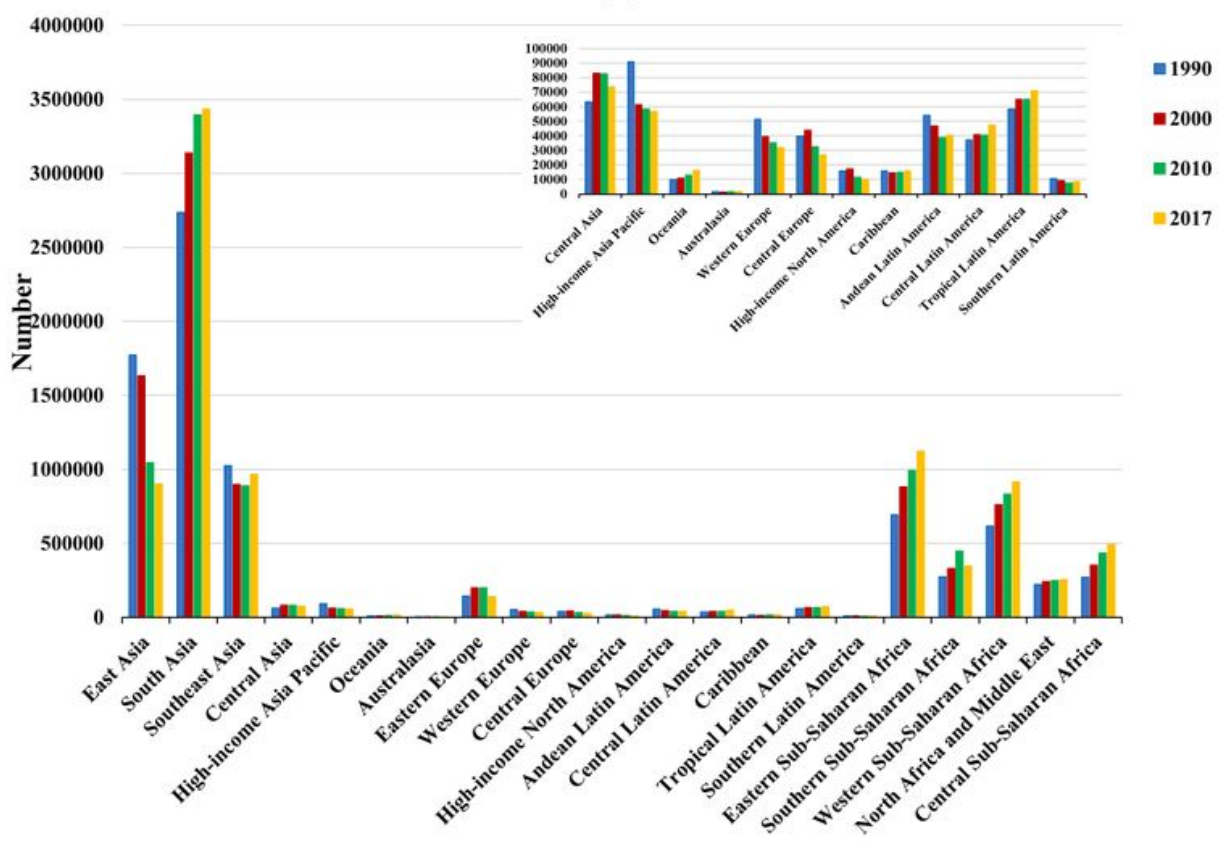

\section{Figure 2}

The distribution in the global incidence of TB, and in SDI areas and geographic regions from 1990 to 2017. (A) The incidence of TB across age groups; (B) Change in incidence of TB in SDI areas; (C) Incidence of TB in geographical regions. 




\section{Figure 3}

The distribution of ASR, percentage changes in absolute number, and EAPCs of TB incidence at national levels from 2000 to 2017, including (A) the ASIR of TB in 2017, (B) the percentage change in the absolute number of TB cases between 1990 and 2017, and (C) the EAPCs of TB. Countries/territories with extreme values were annotated. ASIR, age-standardised incident rate; EAPC, estimated annual percentage change. Note: The designations employed and the presentation of the material on this map do not imply the expression of any opinion whatsoever on the part of Research Square concerning the legal status of any country, territory, city or area or of its authorities, or concerning the delimitation of its frontiers or boundaries. This map has been provided by the authors. 


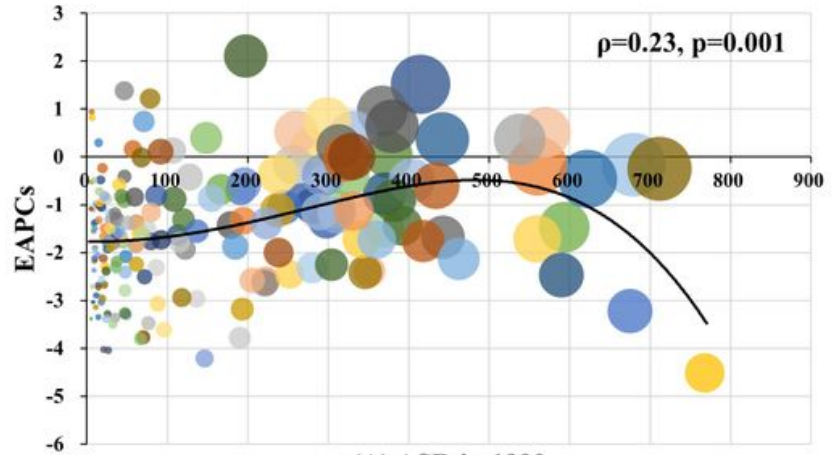

(A) ASR in 1990



(B) HDI in 2017

\section{Figure 4}

The correlation between EAPCs and ASIR in 1990, and HDI in 2017 at national levels. The EAPCs of TB were positively associated with the ASIR in 1990 (A), and negatively associated with the HDI in 2017 (B). ASIR, age-standardised incident rate; EAPC, estimated annual percentage change; HDI, human development index.

\section{Supplementary Files}

This is a list of supplementary files associated with this preprint. Click to download.

- Supplementaryfigure1.jpg

- Supplementaryfigure1.jpg

- Supplementaryfigure1.jpg

- Supplementaryfigure2.jpg

- Supplementaryfigure2.jpg

- Supplementaryfigure2.jpg

- Supplementaryfigure3.jpg

- Supplementaryfigure3.jpg

- Supplementaryfigure3.jpg 
- Supplementaryfigure4.jpg

- Supplementaryfigure4.jpg

- Supplementaryfigure4.jpg

- Supplementaryfigure5.jpg

- Supplementaryfigure5.jpg

- Supplementaryfigure5.jpg

- Supplementarytable.docx

- Supplementarytable.docx

- Supplementarytable.docx 